DOI: 10.20472/IAC.2019.049.008

\title{
SÁNDOR BOZSIK
}

Institute of Accounting and Finance, University of Miskolc, Hungary

\author{
JUDIT SZEMÁN
}

Institute of Accounting and Finance, University of Miskolc, Hungary

\section{ZOLTÁN MUSINSZKI}

Institute of Accounting and Finance, University of Miskolc, Hungary

\section{THE FINANCIAL AND MANAGERIAL PROBLEMS OF SOCIAL ENTERPRISES AND THEIR OPTIONAL SOLUTIONS}

\begin{abstract}
:
The main problems in the social cooperative management are caused by the quality of available human resource and the marketability of products and services. The root of the problems can be found in the quality of labour force and the improper marketing. External specialists are required mostly for administrative duties (in field of book-keeping, taxation and application-writing). The assessment for improving the competitiveness has got less importance. Our questionnaire targeted the economic and financial problems of social enterprises. Based on the result of this survey we created the financing pecking order model for social cooperatives in Hungary. We adapted the traditional pecking order theory invented by Myers (1984) to the financing mix of Hungarian social enterprises. We found that public funds play a dominant role in the external financing of social enterprises (focusing on social cooperatives). State subsidies are most important, but the financial and managerial contribution of local governments is also essential for successful operation. To improve the marketing of products we recommend social cooperatives to use a managerial income statement to determine the most profitable products and markets.
\end{abstract}

\section{Keywords:}

social co-operatives, social enterprises, pecking order theory, controlling, financial management

JEL Classification: L31 


\section{Introduction}

Research related to social enterprises has been strengthening in the recent years in Hungary (Lipták, 2017). All social problems cannot be entrusted solely to the state; well operated social enterprises can successfully handle tasks that the state can manage only withdifficulty or with high costs.

The present paper deals with economic and financial problems related to social enterprises. The main financing and managerial issues and their importance were surveyed in a special segment of social enterprises (i.e. social cooperatives). Based on this questionnaire a financial pecking order theory was created and decision pointswhen the social cooperative should turn from one financing source to another are determined. The model was validated through Hungarian case studies, but hopefully it can be used in the broader Central and Eastern European region.

\section{Typology of social enterprises}

The economic role of social enterprises SEs) is not negligible. According to the European Commission, the social economy includes 2 million enterprises, which means $10 \%$ of all European businesses, and employs over 11 million employees, more than $4.5 \%$ of the EU's working population in 2011 (Cecop, 2014).

A number of papers have attempted to create more specific definitions. Some of these terms are the following:

Social purpose businesses primarily reinvest surpluses in the business or community rather than generating profits for shareholders or owners (OECD, 1999); the definition narrows the concept of SE to social businesses but excludes those enterprises which run public services but are out of direct control of the state.

SEs are third system organisation (based on citizen collaboration, mutuality and self-help to address social needs) that are most engaged in trading within a three-system model of the economy (Pearce, 2003); the definition is hardly understandable without the whole concept of the author.

SEs are organisations that use business methods to achieve social goals (Meadows and Pike, 2010). By this definition the SEs have social goals, but the tools for achieving their goal are business-like. They raise (partly) private funding, their income is generated mostly from the private market. The operation efficiency is crucially important so market-based controlling methods for their special circumstances should be adapted.

SEs are enterprises that bridge the non-profit sector and the social economy and tend towards non-prescriptive but archetypal indicators (distinguishing various economic and social criteria), thereby placing initiatives differentially within a spectrum of social enterprises (Defourny and Nyssens, 2006). The definition is a tautology because the definition contains the defined object.

The common social enterprise characteristics are multi-agency environments, enterprise orientation, social aims, and social ownership (Shaw \& Carter, 2007). This definition reflects the most important features of a social enterprises, but does not tell us whether all elements are required in an organisation to identify it as a social enterprise, or if not, how many. 
Kerlin adopted Salamon's institutional perspective model (Salamon et al., 2000) to compare the size and profile of the non-profit sector across countries and identified some macro-institutional key factors. She stated that the social enterprises' objectives and organisational features are the function of historical traditions, values, existing legal frameworks and discourses with strong national characteristics (Kerlin, 2013, 2015).

However, these definitions do not show the economic environment of social enterprises. Who are the shareholders, what are their main legal form and how do they operate? The Gui model (Gui, 1991) tried to answer these questions. Gui separated three types of interests and gave the ruling form of funding. In his categorisation there are three major drivers or interests that can be found in the overall economy: general interest (Gl) represented by the will of the state; mutual interest $(\mathrm{MI})$, which comes from the common interest of the participants; and capital interest $(\mathrm{Cl})$, which is determined by profit achievement.

In the Central and Eastern European countries the public funds (general interest) play a dominant role in financing the social enterprises, as opposed to the private funds that are mostly dominant in Western-Europe (Nemes, 2018). Significant sources of social enterprise financing are the European Union subsidies. The EU funds cannot be separated from the state funds, as the allocation of European funds is made through the governments (Kocziszky et al., 2017).

We re-examined the original Gui model and found that in Central Europe not only the central state but also the regional and local municipalities play a significant role in founding new social enterprises. Furthermore, the contribution of regional communities has a vital role in the success of social enterprises (Bozsik et al., 2019).

In our modified Gui model, social enterprises can be established from four sides. The initiative can come from the state, from the local municipalities, from non-governmental organisations, from the business sector or from any combination of these partners. Table 1 shows some existing examples for the creation of social enterprises.

Table 1 - Examples of the establishment opportunities of social enterprises

\begin{tabular}{|l|l|l|l|}
\hline Initiator & Supported goal & Legal form & Financing \\
\hline Local municipal & Public work & Public institution & Public funds \\
\hline State & Competitive employment & Social co-operative & Public funds, revenue \\
\hline Market enterprise & Competitive sport & Corporation & Subsidy, ticket revenue \\
\hline Civil organisation & Environmental protection & Association & Membership fees \\
\hline
\end{tabular}

Source: own work

Our target research group is marked by italics. The government wants to subsidise the creation of social cooperatives to transfer people from long-lasting unemployment or public work scheme status to a marketable work force. The organisation form of social enterprise offers a proper institution to manage this transformation.

The Gui model groups the social enterprises under four categories: 
The entrepreneurial non-profit (ENP) model runs an income generating activity to sponsor a social mission. Typical examples are charity activities or non-profit work integration social enterprises that sell their goods or services and train unskilled workers.

The social cooperative (SC) model keeps the organisation form of a traditional co-operative - i.e. equal voting and limitation of capital shares' remuneration - but it combines the private interest with the interest of the whole community or of a specific target group.

The social business (SB) model develops business activities for a social purpose or mission. T ypical social businesses focus their activities on a "social or societal field" such as personal services (for instance elderly care), environmental protection or fair trade. They are non-profit organisations but also market-based companies with a very strong social mission.

The public-sector social enterprise (PSE) model aims to decrease the expenses of public service provision and/or to reach higher efficiency. Local entities take over the job of public authorities in fields of public transport, elderly care or adult education. Their funding, as opposed to social businesses, is mostly public.

To emphasize the importance of public funds, we modified the original Gui model by replacing general interest with governmental and regional interest. The Governmental Interest (GOI) incorporates the will of the central government, while the Regional Interest (RI) expresses the will of local governments (local municipalities and regional entities). Figure 1 shows the modified Gui model, in which Gui's triangle has become a rhombus.

\section{Figure 1 - The modified Gui model}

\section{Governmental Interest (GOI)}

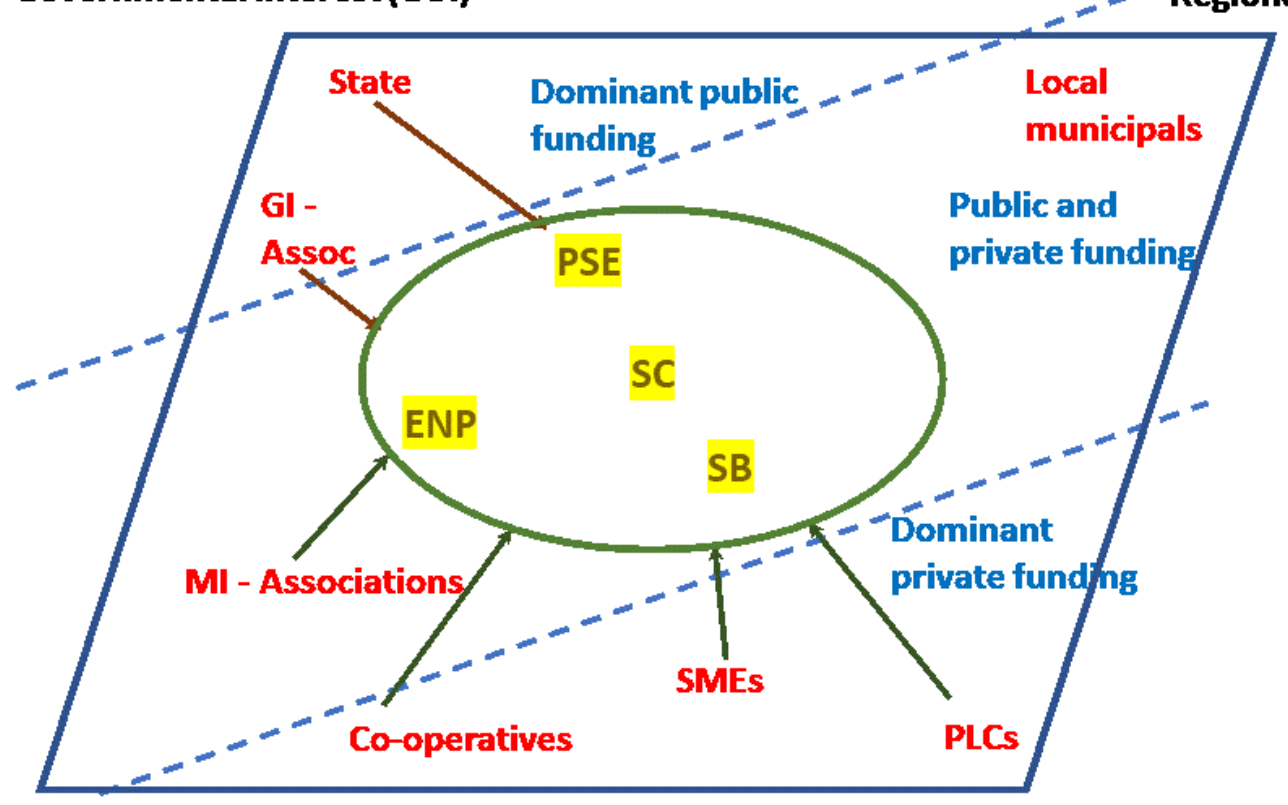

Mutual Interest (MI)

Capital Interest (CI)

Source: Bozsik et al., 2019 


\section{The importance of financing sources at the social cooperatives}

The authors of this article are trainers of a further education training programme for social cooperative managers jointly organized by the Faculty of Economics of the University of Miskolc (GTK) and the supervising organization of social cooperatives - called National Employment NonProfit Limited Company (OFA).

In the frame of this training programme we were able to meet several managers of social cooperatives. A questionnaire was prepared for them to ask their opinions about the economic and managerial problems of social cooperatives. The questionnaire was filled in by 33 people up until the writing of this paper. The sample is not representative.

The distribution of the respondents was the following:

Table 2 - The grouping of respondents by various aspects

\begin{tabular}{|r|r|l|r|l|r|l|r|}
\hline \multicolumn{2}{|c|}{ By gender } & \multicolumn{2}{|c|}{ By education } & \multicolumn{2}{c|}{ By position } & \multicolumn{2}{c|}{ By population of host settlement } \\
\hline male & 21 & $\begin{array}{l}\text { secondary } \\
\text { school }\end{array}$ & 18 & employee & 14 & under 1,000 & 10 \\
\hline female & 12 & college & 9 & member & 9 & $1,000-4,000$ & 5 \\
\hline \multirow{2}{*}{} & university & 6 & executive & 3 & $4,000-10,000$ & 10 \\
\cline { 2 - 7 } & & & president & 7 & $10,000-40,000$ & 4 \\
\cline { 5 - 7 } & & & & $40,000-100,000$ & 4 \\
\cline { 5 - 7 } & & & 33 & & over 100,000 & 33 \\
\hline
\end{tabular}

Source: own work 
Figure 2 - The importance of external financing in the management of social cooperatives

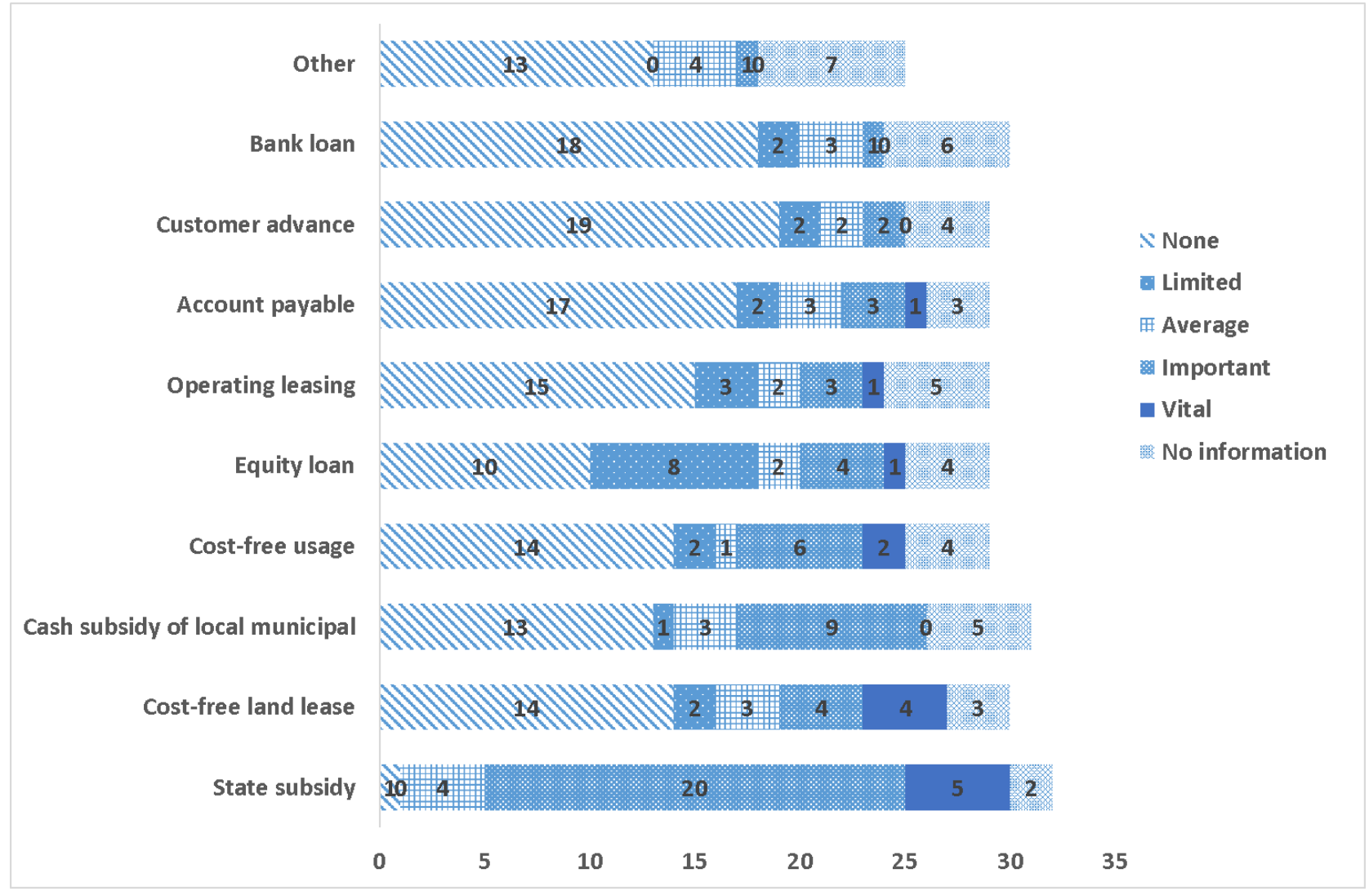

Source: own work

The question about the financing sources was the following: "How important a role do the following financing sources play in your social cooperative?" The respondents evaluated the importance of each of the sources on a 5-point Likert-scale (Figure 2). The number of answers can be read in the middle of each row segment. The financing sources are ranked by their importance in ascending order: the most important source is at the bottom of the figure, the least important is at the top. To calculate the ranking, we took the weighted average of the total answers, so the number of answers were multiplied by the value of the Likert scale, where None $=1$, Limited $=2$, Average $=3$, Important $=4$, Vital= 5, and the answer 'No information' was neglected.

As can be seen from Figure 2, the respondents consider the state subsidy to be the most important source. The rate of 'no information' answers is the smallest here and most of the answers consider it as either important or vital.

In this raw the meaning of the numbers is explained. Only 1 respondent of 33 declared that the state subsidy plays no role in the financing, 4 judged it as average, (nobody answered limited), 20 considers important role, and 5 thought that the state subsidy is vital. 2 respondents have no information. If the row is shorter than the others, some respondents did not evaluate the source at all. 
The second most important financing source is a cost-free land lease provided by the local municipality. Naturally only the agricultural enterprises can use land to support their activity. Here 14 respondents declared that plays no role in the financing of their organisations. But the commitment of the local community is vital for the remaining 13 enterprises. The role of cost-free land lease is vital for 4 of them and important for another 4 respondents.

Besides the state subsidy, the financial support of local municipalities is also important (cash subsidy). More than half of the respondents report this financing source. However, as we can see from the figure, municipal funding plays only an auxiliary role, although 9 respondents declared it important.

The local municipal may provide not only cash subsidies but also contributions in kind, for example, cost-free usage of a plant or operating assets. Only a minority of the respondents declared that it plays some role, but most of that group consider it important.

The fifth most important source, equity loan, is the first liability on the list. It indicates that the activity of the social cooperatives is risky from the point of marketable finance. Equity finance is a hybrid form. Formally, this is a loan provided by a member of the social cooperative (most often it comes from the local municipality) but it is very similar to the equity. The loan has got a very long maturity and its interest rate is often symbolic. In most of the positive answers its role is limited ( 8 of 29 answers).

Operative leasing has almost the same importance as equity loans. Operative leasing is for manufacturing equipment, which occasionally is used for supplementary activities rather than for the core operation (tractors to plough an area, a lawnmower, etc.). The interest bearing leasing is a less common and less important source of finance, and has some role in only 9 cases.

The marketable source of finance (the rest of the financing forms on the lists - accounts payable, customer advances, bank loans and others of this order) plays a less significant role than in a private corporate setup. The role of customer advances and accounts payable is marginal, while bank loans occur only two times among the surveyed cooperatives.

To sum up our analysis on the financing sources of social enterprises, it was found that public funds play an essential role in the external financing of social cooperatives. Direct state subsidy is in the first place, but in fewer than half of the cases cash and in-kind contributions of local municipalities is also important. The marketable forms of financing play only a marginal role.

\section{The traditional model of pecking order theory}

To create the financing model of social cooperatives we adapt the traditional pecking order theory implemented in Corporate Finance (Brealey and Myers, 2005) to the special circumstances of these enterprises. In this model the corporations rank their traditional financing sources by the amount of effort to access them. The corporations first use cheap and easy-to-access sources and turn toward new sources if these are exhausted. 
Figure 3 - The model of pecking order (financing hierarchy)

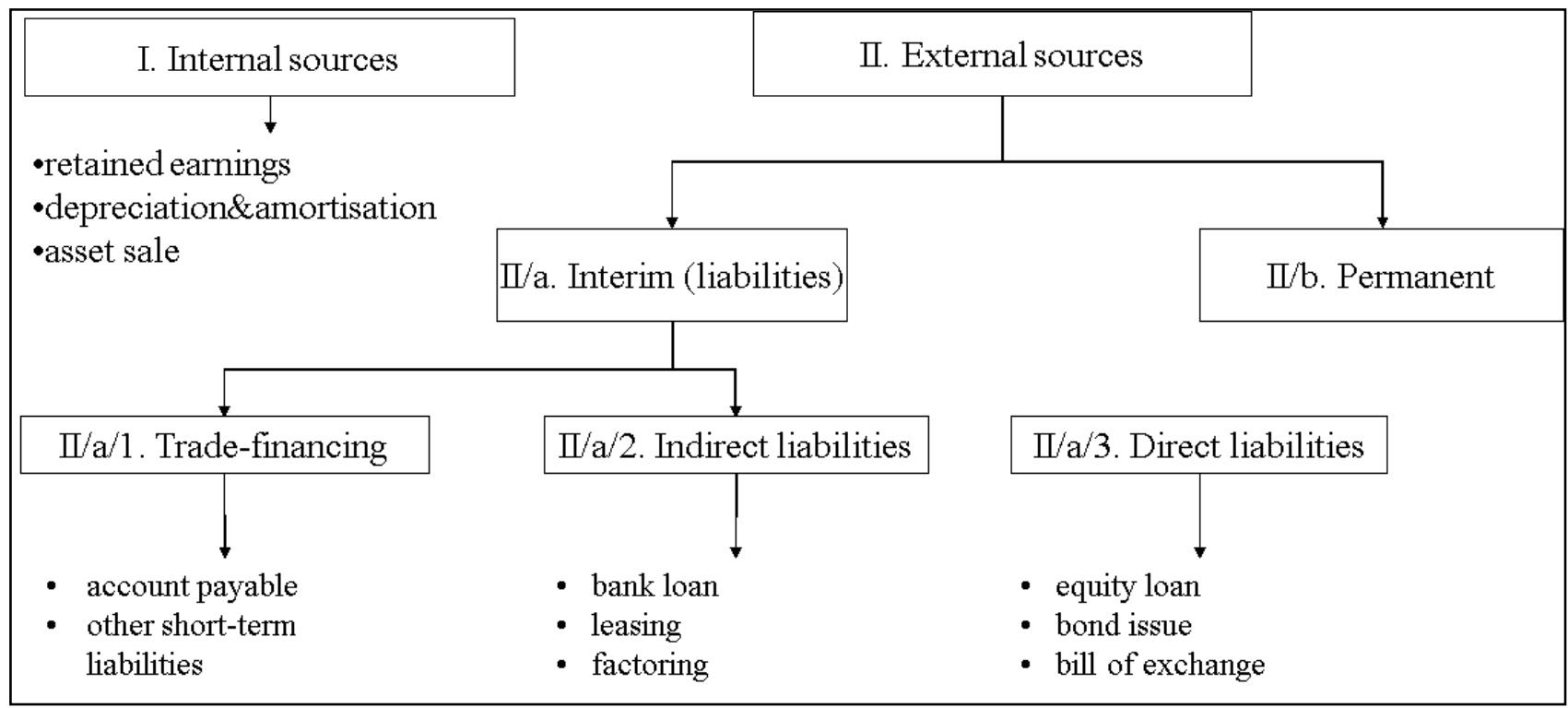

Source: Brealey \& Myers, 2005

In the model the financial manager firstly chooses between the internal and external sources.

Internal sources are incremental cash inflows that come from the operation of corporations. External sources are provided by a legal or private person outside of the corporation.

The internal sources of a company come from the realised, collected sales and other revenues. If the costs and expenses paid are deducted from the incoming cash, we get the volume of internal cash flow.

The main advantage of internal sources is that they can be accessed without any special effort, as the corporation produces them automatically during operation. They do not bear any yield expectation determined in a contract, as opposed to a bank loan for example, so if the company runs into trouble, its liquidity position would not worsen.

In the pecking order theory, enterprises turn toward external sources if the internal sources do not meet their financing needs. External sources can be divided into two groups. The interim (external) sources should be repaid sometime in the future. The most common example of these is the bank loan. Permanent sources need not be repaid, they are available up to the liquidation of enterprises. A typical example of this is raising capital for a company.

It may seem a little strange, but in the traditional pecking order theory if the indebtedness of the corporate is not very high, corporations prefer interim sources over permanent ones. The reason for this is that the owners of corporations do not want to decrease their ownership share, and furthermore the new owners can influence managerial decisions in the internal affairs of corporates. The yield expectation is also higher - due to the higher risk - than the interest rate of loans.

In the pecking order theory, when managers do not consider the indebtedness of the corporate to be high, they prefer to finance their growth plan from interim sources than from permanent ones. 
They will increase the capital base if the indebtedness of the company is too high compared to the optimal levell.

We can group the interim sources (liabilities) into three groups: trade-financing sources, indirect interim sources and direct interim sources. Trade-financing sources are those interest-free sources that are created by the trading cycle. If a company purchases materials, equipment and labour, it does not necessarily pay the bills promptly. Between the delivery and the payment, the suppliers provide the company with cost-free credit. This is used mostly by the larger corporations, and if their dominant position allows it, they lengthen artificially the payment terms. The suppliers can build the financing cost of this deal into their prices - if the strength of competition among the suppliers makes it possible.

VAT debt is a similar cost-free source for corporations. By the Hungarian tax rules, the VAT is due to be paid by the $20^{\text {th }}$ day of month following the settlement period. The settlement period can be month, quarter or year depending on the amount of VAT payment (Act CXXVII of 2007 on Value Added Tax), and during this period the company uses the cash of the public budget costfree. Other examples of cost-free trade financing sources are the cash advance of customers and personnel wages up to the $10^{\text {th }}$ day of the following month.

It is worth mentioning that some authors do not consider the above-mentioned sources as external sources, since they are "automatically" created by the company. However, the traditional internal sources are not burdened by repayment obligation, while the trade-financing sources should be repaid sooner or later.

Indirect interim sources are those liabilities that are provided by a financial institution (bank, leasing company, credit cooperative, factoring company, etc.). Direct interim sources come from issuing debt obligations like a bond, bill of exchange, promissory note or certificate of deposit. Obtaining indirect sources requires less effort than accessing the direct liabilities. To issue securities is a time-consuming process and informing potential investors and gaining the license to issue incur significant expenses. By contrast, getting a loan is a much easier process, especially if the granting bank is the account manager of the corporation, since the bank can then get acquainted with the management of the corporation from its financial reports and other data services.

\section{The pecking order theory of the social enterprises (social cooperatives) based on analysis of the questionnaire}

It came to light from the questionnaire that permanent sources of finance have a dominant role in financing social enterprises. Thus, after the internal sources they determine the financing of social cooperatives. The two basic originators of permanent sources are state programmes and the subsidy of local municipalities.

Liabilities have far less significance; the cost-free liabilities from the local municipalities were most often mentioned. The importance of marketable liabilities is very limited; although the interest-free trade-financing has moderate significance, the role of bank loans is marginal.

If we adapt the pecking order theory to the data revealed by our questionnaire, we gain Figure 4. Within each financing source type the sequence has significance: the more important sources are in the first place of the lists. 
Figure 4 - The pecking order theory adapted to social cooperatives

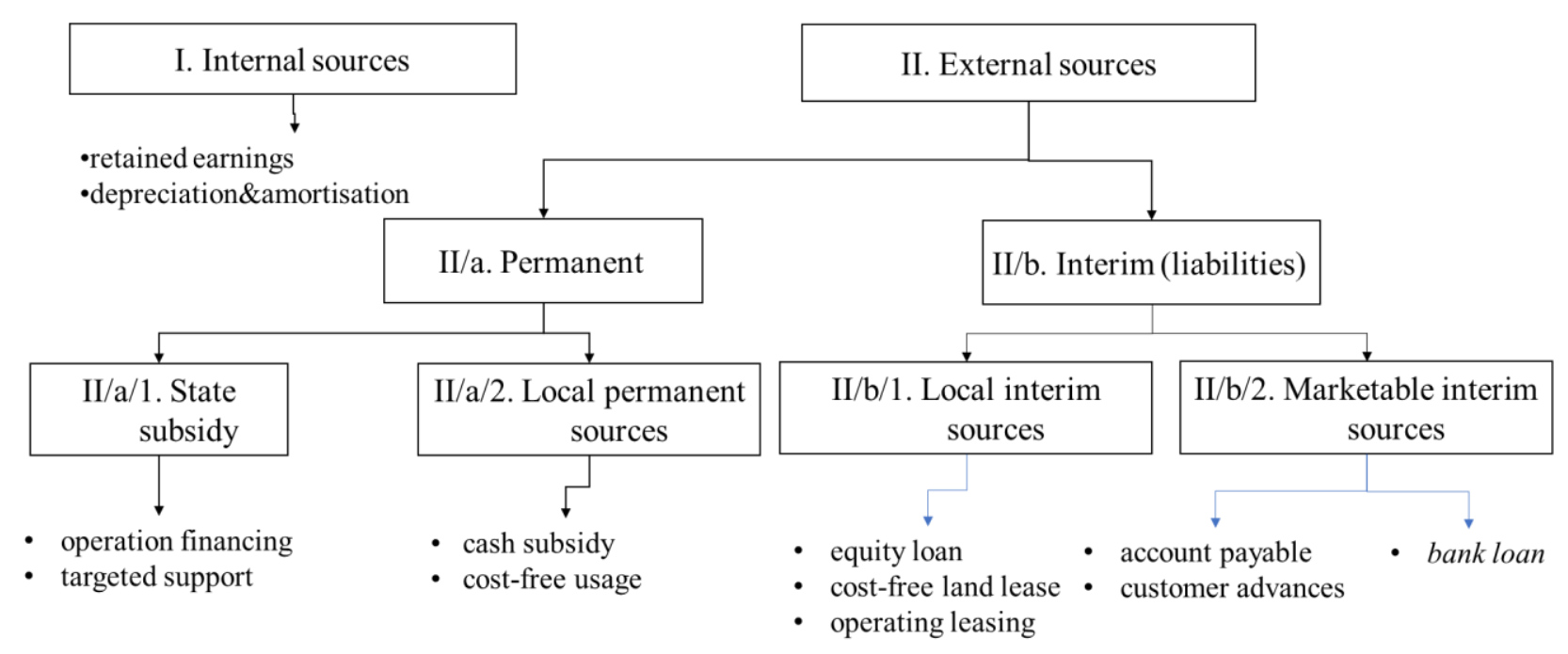

Source: own work

In the category state subsidy an operation-financing source means the subsidies for wage payments. The advantage of this source is that the funds are available within a certain contractual period and if the social cooperative carries the employment obligations determined by the requirements of the state program, it is certain and can be counted on. Targeted support is linked to special purchases. The question related to this issue was the following: "What kind of purpose did your social cooperative apply for funding for in the last two years?" The distribution of the answers is shown in Figure 5: 


\section{Figure 5 - The distribution of individual aids in social cooperatives}

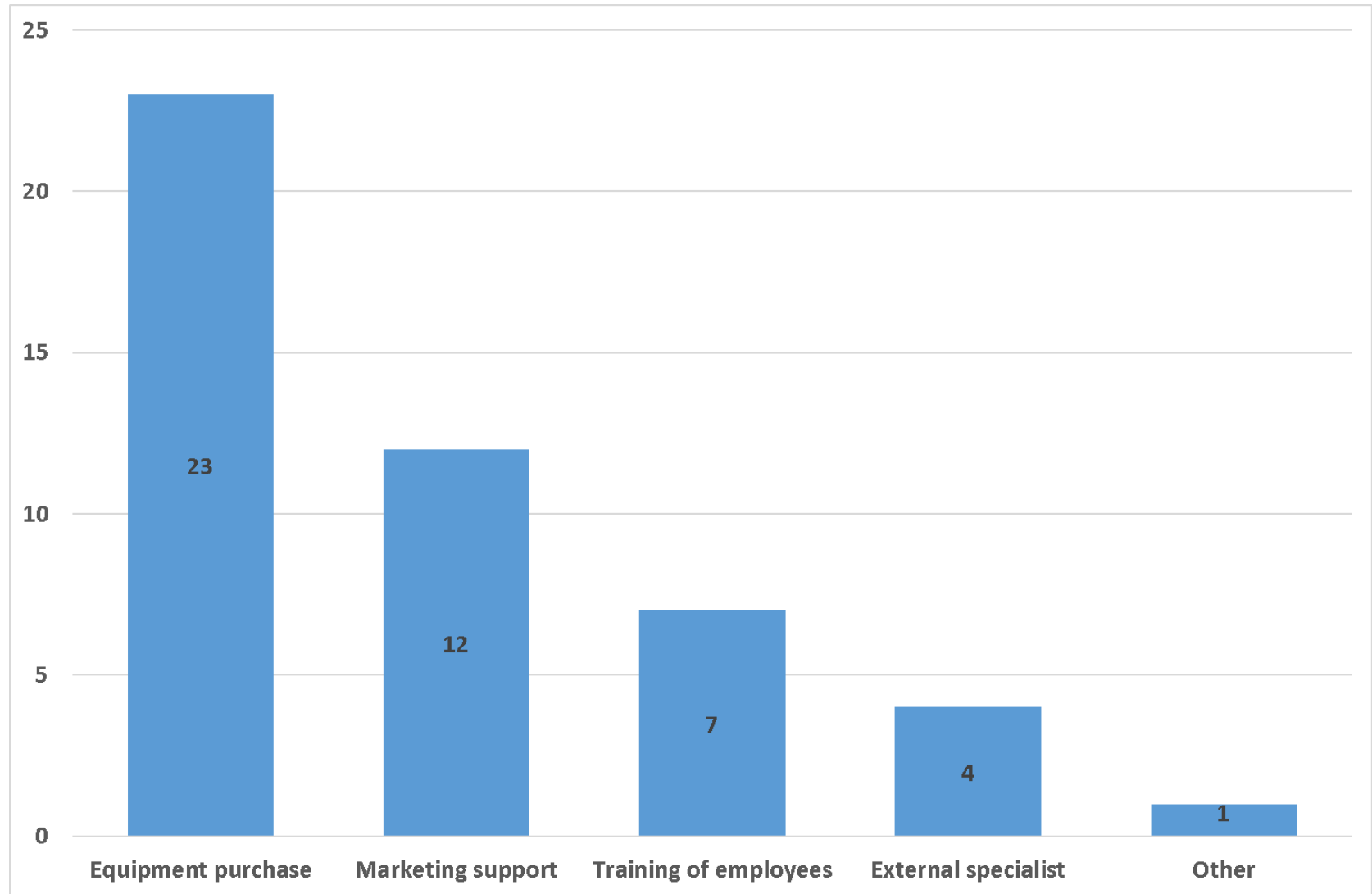

Source: own work

We can see that the equipment purchase was the most frequent purpose, the second was support in marketing and the third was the training of employees.

The second part of permanent sources come from the local municipality where the social cooperatives has its headquarters. This can be cash or contribution in kind. Contribution in kind means the cost-free rent of a building, part of a building or some amount of arable land owned by the local municipality.

The interim sources from local municipalities dominate the liabilities. Equity loans come almost exclusively from the local municipal member of the social cooperative; the role of other members is negligible. Cost-free land lease includes cost-free equipment usage (leasing), while the local municipal requires a rental fee for operative leasing.

The marketable liabilities are at the end of the pecking order hierarchy. Their role is negligible in our survey results. Some answers mentioned creditors as a financing source. Two respondents of the 33 noted the bank loan as a less important financing source, that is the reason why the bank loan is marked by italics.

The social cooperatives required external specialists mainly for administrative duties (bookkeeping, taxation, and writing project proposals and applications, in this order). The specialist work to strengthen competitiveness has less significance. 


\section{Managerial problems of social cooperatives}

The second issue addressed in the questionnaire was the managerial problems of social cooperatives. The question was the following: "Please rank by importance of the following problems in the management of your social cooperative".

Sixteen potential sources of managerial problems were listed, and the respondents were asked to rank the problems by their seriousness in the economic management of their organisation. The answers are presented in Figure 6.

\section{Figure 6: Significance of economic problems in the management of social cooperatives}

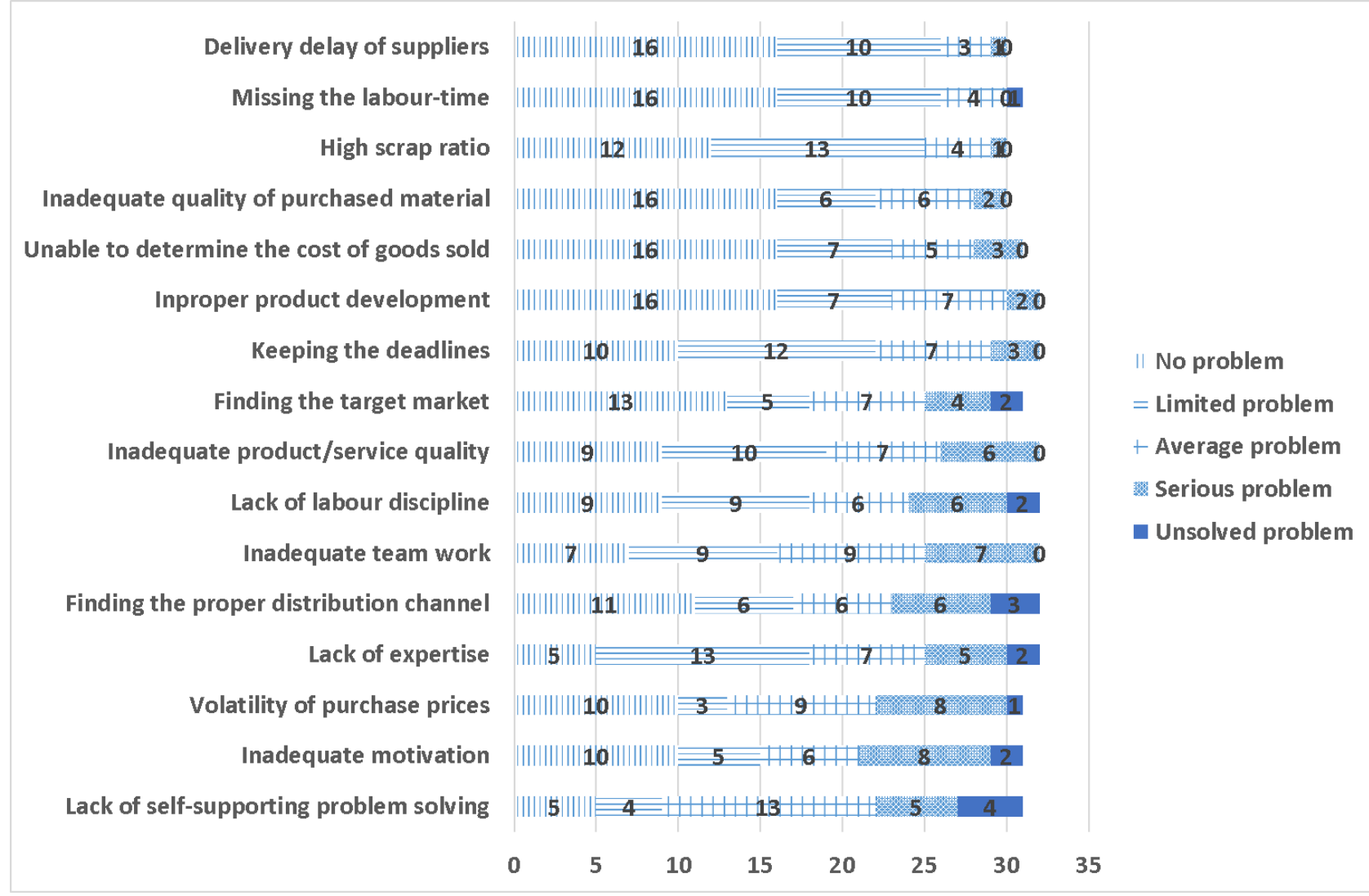

Source: Own editing

The structure of Figure 6 is very similar to that of Figure 2. The respondents evaluate the importance of each of the sources on a 5-point Likert scale (no problem - 1; limited problem - 2; average problem - 3; serious problem - 4; unsolved critical problem - 5). The weighted average of the answers was calculated, where the weights were the number of answers in each category. To calculate the ranking, we took the weighted average of the total answers and ranked them in ascending order, so the least important problem is at the top, while the most important one is at the bottom.

If we look at the rank of the problem, the most serious problems are caused by the work force: lack of self-supporting problem solving ( $1^{\text {st }}$ on the list), inadequate motivation $-\left(2^{\text {nd }}\right)$, lack of 
expertise on the part of employees $\left(4^{\text {th }}\right)$, inadequate teamwork $\left(6^{\text {th }}\right)$ and lack of labour discipline $\left(7^{\text {th }}\right)$. Almost every aspect of the work force is critical except for missing work, which is a negligible problem. This is no wonder, as the workers are usually paid by their working hours regardless of their performance. The condition of granting state subsidy is the employment of a certain number of employees, so if a social cooperative dismisses an employee, a new one should be hired. Considering the fact that these social cooperatives are mostly operating in small settlements (see Table 2), it can be a very hard task to find new workers to replace unsatisfactory employees.

The main aim of the state subsidy is to help people to transfer from long-lasting unemployment or public work scheme status to marketable employment. But the answers to this question indicate that this transformation is not an easy job. To improve the quality of available work force requires the constant supervision of the management and the targeted training of the employees to satisfy the labour market requirements.

The respondents perceived the second main problem group to be related to improper marketing: finding the proper distribution channel (ranked at $5^{\text {th }}$ biggest problem of 16), inadequate product/service quality $\left(8^{\text {th }}\right)$, finding the target market $\left(9^{\text {th }}\right)$ and improper product development $\left(11^{\text {th }}\right)$. The social cooperatives mostly work up local raw materials and sell them in nearby markets. Considering the fact that they are new organisations and definitely small ones (see Table 2), their brand strength is very limited. They cannot compete with prices, because the costs of operation are high due to the improper work force and the limited scale of production. To break out from this trap requires proper business cases and perfect implementation of business plans.

Another issue is related to the uncertainty of purchasing: the volatility of purchase prices ranked as the $3^{\text {rd }}$ biggest problem. The other problems relating to purchasing are far less important: reliability of purchase quality $\left(13^{\text {th }}\right)$, delivery delay of suppliers (last place). The quality management of internal processes (meeting deadlines $\left(10^{\text {th }}\right)$, unable to determine the cost of goods sold $\left(12^{\text {th }}\right)$, high scrap ratio $\left.\left(14^{\text {th }}\right)\right)$ is less important.

To sum up our results, by far the most important problem of the management of social cooperatives is the improper quality of the labour force. Almost every aspect related to human resource management was considered a critical factor. Marketing problems are also important, while the issues related to internal processes and purchasing are less significant.

\section{Optional solutions to the managerial problems}

The main line of our research is how the managers of social cooperatives can use the databases available at their organization to make proper decisions. The framework of the structured usage of databases was worked out by Kaplan and Norton (Kaplan \& Norton, 1992) and it is called the Balanced Scorecard System (BSC). The viewpoints of the basic model are the financial, the customer, the internal processes, and the learning and growth viewpoint.

Bull's paper analysed the results of 30 pilot social enterprises utilising the BSC system. The paper concluded that highlighting both strengths and areas where greater support may be required would be a great help for these enterprises (Bull, 2007). He stated that the general strengths of the SEs in his investigation was the learning perspective (i.e. training and development, 
participative decision-making and personal development cultures). Another strong area was the vision and strategy creation ability. The weaknesses were the low level of management systems, from accounting to quality standards. The reason is the shortage of resources like financial literacy and professional skills.

Bull also modified the original BSC model for SEs by modifying the four perspectives into multibottom line (dealing with synthetic assessment of financial, environmental and social results), stakeholders' environment, internal activities (related to structure, communication, quality, etc.), and learning organization (dealing with training and knowledge management).

Figure 7 - Bull's Balance Model and Topic Areas

\section{Return: The multi-bottom line}

Social Accounting

Sustainability

Budgets

Social Aims

Environmental Aims

Metrics

Branding

Promotion

Evaluation

Stakeholder Focus

Market Awareness

\section{The stakeholder environment}

\section{A learning organisation}

Learning Culture Improvement

Participation

Knowledge

Continuous Improve.

Training

Structure

Communication

Quality

Standards

Frexibility

Performance Measures

\section{Internal activities}

Source: Bull, 2007

In our analysis the main problem of social cooperatives is related to human resources. The monitoring of this problem is treated by the human resource and learning perspective of BSC. The key point of the learning perspective is: How can the employees and the management treat the challenges of the continuously changing economic environment; how quick is the implementation of appropriate responses?

The key point of the customer perspective is: How do customers judge the performance of the organization? When designing a customer perspective, it is necessary to identify the customers and the market segments in which the organization wants to compete. Financial goals can only be met by the organization if it produces products or services that customers value. It is not 
possible to satisfy every customer's needs, so it is advisable to set target values by segment. Thus, the customer aspect basically focuses on the long-term relationship with the customers being fruitful and durable. Based on Kaplan's and Norton's recommendations (Kaplan and Norton 1992), the related indicators are the market share, product range, customer satisfaction, complaints, returns, customer group profitability, retained and new customers, etc. (Musinszki and Süveges 2019).

The purchase problems can be well treated by the internal processes' perspective of BSC, as can the quality management. That is the reason why the classic Bull model is modified reflecting the problems detected by our questionnaire. Financial accountability is an important part and key issue for every enterprise, so we only slightly modified the left upper segment. However, we replaced the environmental aims with financial and environmental sustainability.

One of the missions of social enterprises is to help their members to develop and improve important labour market capabilities. Due to this, in the learning organization perspective we inserted new aspects which emphasize the improvement of the competitiveness of the labour force. This part is considered the most important part of the BSC, because the success of improving the human resource factors will improve the financial perspective.

The stakeholder environment was dramatically restructured. Instead of it we place the requirements of the grantor and regulator public institutions. Most of the social enterprises depend on public funds, so the enterprises should meet the criteria of the state and European Union funds. There may be numerous types of available state funds. Especially in agriculture and rural development there are several opportunities (Olajos, 2019).

The internal activities strive to enhance the efficiency of operations. We plan here only one modification. How can the social enterprise develop the members' relevant labour market abilities?

To monitor the dedicated issues of a BSC system, the size of the problem should be measured by indicators, the frequency of measurement should be determined, and furthermore the potential actions to improve the indicators should be identified.

Figure 8 shows the result of our considerations fit to the request of public donors. The suggested modifications in the original model are shown in bold. 
Figure 8 - Further developed Bull model for social cooperatives

\begin{tabular}{|c|c|c|c|}
\hline \multicolumn{2}{|c|}{ Return: The multi-bottom line } & \multicolumn{2}{|c|}{ A learning organisation } \\
\hline \multicolumn{2}{|c|}{$\begin{array}{l}\text { Social Accounting } \\
\text { Financial and environmental } \\
\text { sustainability }\end{array}$} & & \multirow{2}{*}{$\begin{array}{l}\text { Learning Culture } \\
\text { Improvement } \\
\text { Participation } \\
\text { Marketable competence } \\
\text { Adaptation of labour } \\
\text { market skills }\end{array}$} \\
\hline $\begin{array}{l}\text { Social Aims } \\
\text { Labour market cost }\end{array}$ & \multirow{2}{*}{\multicolumn{2}{|c|}{$\begin{array}{c}\text { Visioning } \\
\text { (Sustainable labour market } \\
\text { activity and fulfilling other } \\
\text { social goals ) }\end{array}$}} & \\
\hline $\begin{array}{l}\text { Structure and } \\
\text { compensation of }\end{array}$ & & & $\begin{array}{l}\text { Structure } \\
\text { Communication }\end{array}$ \\
\hline \multicolumn{2}{|c|}{$\begin{array}{l}\text { employees } \\
\text { Fit to the request of } \\
\text { financing organisations } \\
\text { Financial and non-financial } \\
\text { reports }\end{array}$} & & $\begin{array}{l}\text { Quality } \\
\text { Standards } \\
\text { Developing labour } \\
\text { market skills } \\
\text { Performance Measures }\end{array}$ \\
\hline \multicolumn{2}{|c|}{ Fulfil the request of public donor } & \multicolumn{2}{|c|}{ Internal activities } \\
\hline
\end{tabular}

Source: own work

The interpretation of the figure begins from the left upper corner and moves anti-clockwise. The multi-bottom line means that the social cooperatives have duel goals - both market-oriented and social. The market goal is to increase the equity of the organisation by achieving a positive net income, which is the bottom-line figure of the income statement. The social goal can be seen in the very middle of the figure - to provide sustainable employment of the members and create a marketable work force from the employees.

The financial sustainability reflects the market goal. The organisation should be profitable (the proposed indicator is the ROE - return on equity - where the net income is divided by the equity of the social cooperatives). Another profitability indicator could be also used - for example Return on Assets or EBITDA ratio.

The labour market cost is essential, because the operating state subsidy can cover $50-100 \%$ of this expense. Replacing the state subsidy with the organization's own revenue is the key success indicator of the social cooperative. The proposed indicator here is the operating state subsidy/total labour cost - which should be reduced over time. Another indicator could be the operating state subsidy/operating profit. If the ratio is less than one, the organisation can be considered a sustainable organisation, because it is able to survive without the operating state subsidy. 
The above indicators are used to measure the result of the operations, but they are unable to measure the reasons for success or failure. From the questionnaire we see that the major problem is the quality of the available work force. So, the improvement of human resources by learning and by motivating is essential. The upper right quarter of our proposed BSC is related to this issue.

The marketable competence can be measured by several indicators, but they are industry specific ones. Each industry requires special features. For manufacturing enterprises, the proper quality of craftsmen can be regularly tested, and an essential training program should be introduced. Here the proposed indicators are the ratio of skilled and unskilled labour force. The successful completion of vocational training programs is also worth measuring. Independent projects should be launched with the management of a team leader in order to improve teamwork and raise motivation. The goal and reward of these projects should be specifically determined, and their continuous monitoring is required.

Various requirements can be set by donor public organisation. They often prescribe the number of employees or members and the length of their employment, and they can limit the amount of payable transfers. In addition to the circumstances of employment, they can demand numerous data about the activity of the social enterprises, determine the major accounting and taxation policy rules, specify the structure and content of financial reports, and they can require a financial budget. Public institutions can act as an external control over the business of social enterprises.

\section{Conclusions}

The focus of our paper is the management of social enterprises with special regard to social cooperatives. The role of social enterprises is increasing, and research in this area should address the emerging challenges of their management. In Hungary one of the most important goals of social enterprises is that they can improve labour-related skills to transition people from long-lasting unemployment or public work scheme status toward the competitive labour market.

The focus of our research is the financial and managerial problems of social enterprises, and our questionnaire survey tried to rank the weight of these issues. Optional solutions were created to reflect some of the emerging problems.

The first output of our study is the modified pecking order hierarchy that can be seen in Figure 4. The model adaptation was informed by the analysis of our questionnaire review. The second output, which can be seen in Figure 8, is an adaptation of the Balanced Scorecard framework to the needs of social enterprises.

The other main conclusions are the following:

1. Public funds play the dominant role in financing the social cooperatives. State programs including EU funding are in the first place, followed by cash and in-kind contributions of local municipalities. The form of marketable liabilities plays a marginal role.

2. The most important problem of the management of social cooperatives is the improper quality of their labour force. Almost every aspect related to human resource management was considered a critical factor. Marketing problems are also important, while the issues related to internal processes and purchasing are less significant. 
3. The social cooperatives required external specialists mainly for administrative duties (bookkeeping, taxation, and writing project proposals and applications, in this order). The specialist work to strengthen competitiveness has less significance.

\section{Acknowledgements}

This research was supported by the project no. EFOP-3.6.2-16-2017-00007, titled Aspects on the development of intelligent, sustainable and inclusive society: social, technological, innovation networks in employment and digital economy. The project has been supported by the European Union, co-financed by the European Social Fund and the budget of Hungary.

\section{References}

Act CXXVII of 2007 on Value Added Tax, Hungary.

Bozsik S., Musinszki Z.,\& Szemán J. (2019) "A Central European approach to the typology of social enterprises" In: Proceedings of the $13^{\text {th }}$ International Conference of Strategic Management and its Support by Information Systems SMSIS 21-22 May, 2019 Ostrava Czech Republic ISSN: 2570-5776 pp. 25-32.

Brealey R., Myers S.C. (2005): Modern Vállalati Pénzügyek I. Panem ISBN 9637628134

Mike Bull, (2007) "'Balance": the development of a social enterprise business performance analysis tool", Social Enterprise Journal, Vol. 3 Issue: 1, pp.49-66, https://doi.org/10.1108/17508610780000721

Cecop (2014) Social cooperatives at the high-level debate during the European Commission conference on social enterprises, January 20, 2014. http://www.cecop.coop/European-Policymakers-agree-on-the

Defourny, J. and Nyssens, M. (2006) "Introduction: Defining Social Enterprise", in Nyssens, M. (ed.) Social Enterprise: At the Crossroads of Market, Public Policies and Civil Society, Abingdon: Routledge

Gui, B. (1991) The Economic Rationale for the "Third Sector", Annals of Public and Cooperative Economics, Vol. 62, No. 4, pp. 551-72.

Kaplan, R. S. and Norton, P. D. (1992) The Balanced Scorecard - Measures That Drive Performance, Harvard Business Review, 92/1-2, Pp. 71-79.

Kerlin, J. (2013) "Defining Social Enterprise across Different Contexts: A Conceptual Framework Based on Institutional factors", Nonprofit and Voluntary Sector Quarterly, Vol. 12, No. 1, pp. 84-108.

Kerlin, J. (ed.) (2015) “Kerlin's Macro-Institutional Framework”, Social Enterprise Journal, special issue, Vol. 11, No. 2.

Kocziszky, G., Veresné, S.M. and Balaton, K. (2017). A társadalmi innováció vizsgálatának tapasztalatai és fejlesztési lehetőségei, Vezetéstudomány, Vol. 18, No. 6-7, pp.15-19.

Lipták K. (edited) (2017) „Társadalmi innováció és felelősségvállalás Észak-Magyarországon” Miskolci Egyetem Gazdaságtudományi Kar ISBN 978-963-358-135-3

Meadows M. and Pike, M. (2010). Performance management for social enterprises. Systemic Practice and Action Research, Vol. 23, No.2 pp. 127-141. http://dx.doi.org/doi:10.1007/s11213-009-9149-5 
MUSINSZKI, Z. and SÜVEGES, G. B. (2019) Strategic decision-making supported by traditional financial indicators, Oradea Journal of Business and Economics Vol. 4, No. 1. pp. 29-37.

Myers, Stewart C. (1984). "Corporate financing and investment decisions when firms have information that investors do not have". Journal of Financial Economics. 13 (2): 187-221. doi:10.1016/0304405X(84)90023-0

Nemes G. (2018) „A társadalmi innováció és integrált vidékfejlesztés - két jó gyakorlat” Északmagyarországi Stratégiai Füzetek XV. évf. 69-78. oldal

OLAJOS I. (2019) A fiatal gazda tematikus alprogram, mint a támogatási rendszer kiemelt eszköze Publicationes Universitatis Miskolciensis Sectio Juridica at Politica (in press)

OECD (1999) Social Enterprises, Organisation for Economic Co-operation and Development .Paris: OECD Noya, A. \& Lecamp, G. (1999) Social Enterprises. Organisation for Economic Co-operation and Development (OECD): Paris.

Pearce, J. (2003) Social Enterprise in Anytown, London: Calouste Gulbenkian Foundation.

Salamon, L., Sokolowski, W. \& Anheier, H. (2000) "Social Origins of Civil Society: An Overview", Working Paper of the Johns Hopkins Comparative Nonprofit Sector Project, no. 38, Baltimore: The Johns Hopkins Center for Civil Society Studies

Shaw, E. \& Carter, S. (2007) "Social entrepreneurship: theoretical antecedents and empirical analysis of entrepreneurial processes and outcomes", Journal of Small Business \& Enterprise Development, 14(3), pp. 418-34. Social Enterprise Models (ICSEM) Project 